\title{
DIFFERENT INFLUENCE ANALYSIS OF SUNSET POLICY AND TAX AMNESTY TO THE RETAILER/ SMALL AND MEDIUM SIZED ENTERPRISE INDIVIDUAL TAXPAYER COMPLIANCE
}

\author{
Yuliana Gunawan, Lidya Agustina dan Enrico Goiyardi \\ Maranatha Christian University \\ yuliana_ok99@yahoo.com
}

\begin{abstract}
As we all know, tax is one of the most essential source of a state income which reaches up to $70 \%$ of the total. The target of tax payment has always increased every year, together with the increasing need of state expenses. Many breakthrough has been made since the onset of tax reformation in 2002 in order to facilitate the tax payers in fulfilling their duty as well as to reach the target of tax proceeds. One of those breakthrough is Sunset Policy, and the other is Tax Amnesty. The Population used in this research is non-employee individual taxpayer enlisted in the Tax Office of Majalaya, Bandung City, using qualitative data (the primary data obtained from questionnaire result). Sampling data drawn from simple random sampling method. Data analysis method used is the Simple Regression analysis which has passed the validity, reliability and classical assumption tests combined $t$-test. The result of this research shows that there is a significant influence of both Sunset Policy and Tax Amnesty variable to the tax compliance of the individual tax payer, with the Sunset Policy conveys greater impact than the latter.
\end{abstract}

Keywords: tax amnesty, sunset policy, tax compliance of the individual tax payer

\section{INTRODUCTION}

Tax reformation which started in 2002 has given some breakthrough in the tax system mainly to assist the taxpayers in fulfilling their duty as well as to achieve the target of state tax income. Those assistance are E- filing tax return, E- registration, E- billing for tax payment, E- tax invoice, contact centre provider and the simplified form for the taxpayers to fill in.

Nevertheless, the tax compliance still shows less significant numbers In spite of those improved facilities, we see that the taxpayers compliance has not been satisfactory yet.

Tax Amnesty and Sunset Policy are the ways to enhance tax compliance. Sunset Policy erased the late tax payment administrative penalty for those who had registered for Tax Identification Number, as it is stated in article 37A Law no. 28 of 2007 concerning the Third Amendment Of The Law Number 6 Year 1983 On General Provisions and Taxation Procedure.

The first Sunset Policy in 2008 was considered a success for it gained 7.46 
trillion Rupiahs.Nevertheless, the tax compliance gradually decreased after Sunset Policy ended.

Tax Amnesty is a limited time opportunity for a specified group of tax payers to pay a defined amount, in exchange for forgiveness of tax liability (included interest and penalties) relating to the previous tax period or periods and without fear of criminal prosecution.

Thus, the writers decided to analyze the different influence analysis of Sunset Policy and Tax Amnesty to the retailer/ small and medium sized enterprise individual taxpayer compliance in the region of Majalaya tax office, Bandung city.

\section{LITERATURE REVIEW}

\section{Tax}

Mardiasmo (2013:1) defines tax as following: Tax is a mandatory financial charge to the government according to the enforced law, which has no direct counter-service, to fund public expenditures.

\section{Sunset Policy}

It is the measure within a regulation or other law that provides that the law shall cease to have effect (interest, penalties, fine or surcharge) after a specific date, unless further legislative action is taken to extend the law as it is regulated in article 37A Law of Provisions and Tax Procedures.

The abolition of tax-interest penalties for the unpaid or underpaid tax were given to the followings:

1. Personal and corporate tax payers who had owned the Tax Identification Number (TIN) and set up the correction of annual income tax return before 2007 which escalated the tax arrears.

2. Personal tax payers who had not owned the Tax Identification Number
(TIN) yet , but voluntarily registered for having one.

In 2008 sunset policy was a success since it gained extra 7.46 trillion of tax payment and it was proved to exceedingly over the target of income within the last ten years.

\section{Tax Amnesty}

According to the Law of Indonesia number 11, 2016, tax amnesty is the removal of the debt tax- no administrative or criminal penalties are charged- by revealing assets/ property and pay tax ransom as it is regulated in Article 1.

For the tax payers whose gross income is up to 4.8 billion as it is reported on the first tax report, the ransom is:

(a) $0.5 \%$ for those who report their assets up to 10 billion in the statement letter

(b) $2 \%$ for those who report their assets more than 10 billion in the statement letter, submitted within the first month since the Act no 11, 2016 is enforced and valid until March 31st 2017.

The net worth is the difference between the property subtracted with the debt, meanwhile to receive the amnesty (as it is regulated in article 8, Law no. $11,2016)$ a tax payer has to report a statement letter to the Minister of Finance, signed by the personal tax payer, the highest chief according to the deed of establishment or another correlated document (for the corporate tax payer or the endorse, in case the highest chief is absent).

The tax payer has to fulfill the following rules:

1. Owned Tax Identification Number

2. Paid the tax ransom

3. Paid off all his tax arrears

4. Made a settlement for all his under paid or unpaid tax that should not be returned to him in the initial proof- 
preliminary-examination/ investigation

5. submitted annual income tax return for those who has the responsibility to report the annual income tax return

6. Re evocate the application:

- refund overpaid taxes

- reduce or remove administrative penalties in the tax assessment or tax collection letter which contained the tax principle of the tax due

- reduction or cancellation of unrightfully tax assessment

- tax objection

- revision of tax assessment and tax decision letter

- tax lawsuit

- judicial review when tax payer is applying tax deferment request and there is still no tax court verdict published yet. The ransom has to be fully paid to the state treasury through the Percept Bank. The ransom uses tax payment slip as the ransompayment evidence after being verified.

\section{Tax Rates for Micro, Small and Medium Enterprises and The Definition of Micro, Small and Medium Enterprises}

For micro, small and medium enterprises with income up to 4.8 billion Rupiah, the tax rate is $0.5 \%$ for asset value up to 10 billion Rupiah and 2\% for asset value more than 10 billion Rupiah, in July $1^{\text {st }}, 2016$ - March 31 $1^{\text {st }}, 2017$. Micro, small and medium enterprises here are Taxpayers, both Individual or Entity, as long as their only source of income is the 4.8 billion Rupiah business in the last Tax Year and do not receive any other income from under contract-jobs or free jobs (Darussalam, 2014).

\section{Taxpayers' Compliance}

According to Abdul Rahman (2010:32) in Nurhidayah (2015) taxpayers' compliance could be defined as a state in which taxpayers fulfill all of their tax obligations and execute their taxation rights.

According to Mardiasmo (2011:56) Taxpayers have several obligations to fulfill, which are :

1. Signing up into the system to gain taxpayer's identification number.

2. Reporting their businesses as taxable entrepreneurs.

3. Calculating their tax payable.

4. Collecting the corporate income tax return, filling it in truth and admitting it to the Tax Office within the fixed deadline.

5. Administering bookkeeping/accountancy.

6. If the taxpayers are being audited, they are obliged to :

a. Disclose their accounting notes and records which record the income gained, business activities, other jobs the taxpayers do or tax object payable.

b. Provide cooperation to assist the auditing process, such as allowing the auditors to confirm on certain office if necessary.

7. If the taxpayers are bounded with an obligation to conceal some details during the books disclosure, recording or documentation process, then the concealment has to be removed for the sake of auditing.

\section{Taxpayers' Compliance Indicators}

Based on the $16^{\text {th }}$ Act in 2009 about Basic Tax Requirements and Procedures, the indicators for taxpayers' compliance are the following :

1. Compliance in fulfilling every subjective and objective requirement and registering 
themselves to Tax Offices near their home or work address (to get their own Tax Identification Number (TIN), which they will use in executing all of their rights and obligations).

2. Compliance in tax payable calculation and payment.

The calculated tax will be transferred to the Government via banks or post office by using Tax Payment Slip.

3. Compliances in paying tax arrears.

Tax arrears are the tax payables the taxpayers had not paid and the overdue fine.

4. Compliances to report the Tax Return.

Taxpayers are obliged to fill and report their Tax Return to the Tax Office within the deadline. The deadline is maximum 20 days after the end of the tax period, and as for the Annual Tax Return it is maximum 3 months for individual taxpayers and 4 months for entity taxpayers after the end of the tax year. Taxpayers will get administrative sanctions if they are late or failed to report the Tax Return.

\section{Hypotheses}

Based on the description above, the hypothesis can be formulated as follows: $\mathrm{H}_{1}=$ There is an effect of sunset policy towards the individual taxpayers' compliances, which are small retailers in the region of Majalaya Tax Office in Bandung.

$\mathrm{H}_{2}=$ There is an effect of tax amnesty towards the individual taxpayers' compliances, which are small retailers in the region of Majalaya Tax Office in Bandung.

$\mathrm{H} 3$ = There is a difference of sunset policy effect and tax amnesty effect on the individual taxpayers' compliances, which are small retailers in the region of Majalaya Tax Office in Bandung.

\section{RESEARCH METHOD}

\subsection{Data Collection Techniques}

Population is the generalization area consisting of objects or subjects that have certain qualities and characteristics which set by the researcher to be studied and to be drawn the conclusion (Sugiyono, 2011: 117). Population is the whole objects which characteristics will be tested (Suliyanto, 2006). The population in this research is all the nonemployee personal taxpayer who is registered in the area of KPP Pratama Majalaya in Bandung. Sample is a part from the amount and the characteristics which is had by the population (Sugiyono, 2011:118). The good sample is the sample that can be used to describe the characteristics of the population (Suliyanto, 2006).

\subsection{Sample Collection Techniques}

The sampling technique which is used is purposive sampling which is intentionally taken according to the sample requirements. The sample in this research is the individual retailer taxpayer which is registered in the area of KPP Pratama Majalaya in Bandung.

\subsection{Data Analysis Techniques}

Data analysis method used is the Simple Regression analysis which has passed the validity, reliability and classical assumption tests combined t-test

\subsection{Simple Regression Analysis}

$\mathrm{Y} 1=\alpha+\beta 1 \mathrm{X} 1+\varepsilon$
$\mathrm{Y} 2=\alpha+\beta 2 \mathrm{X} 2+\varepsilon$

Information:

$\mathrm{Y} 1,2=$ the compliances of nonemployee taxpayer

$\mathrm{X} 1=$ Sunset Policy 
$\mathrm{X} 2=$ Amnesty Tax

$\alpha=$ constant

$\beta=$ regression coefficient

$\varepsilon=$ Error

\section{RESULTS AND DISCUSSION}

\subsection{Results}

In this research, the data collection is done by distributing the questioners to the individual retailer taxpayer in KPP Pratama Majalaya in Bandung. The questioners are distributed to 100 respondents. In the contrary, the data that is required from the respondents that has business / entrepreneur is only 73 data. The respondent that has income < 400 million / month is only 46 respondents out of 73 respondents. Thus, there are 46 respondents which fulfilled the requirements for the research.

\section{Research Instrument Testing}

\section{Validity Testing}

In this testing, the validity test uses the Pearson method. The result of the validity test in the entire dimension in variable $\mathrm{X}$ and $\mathrm{Y}$ in this research is valid because the item value is bigger than 0 , 3.

\section{Reliability testing}

The reliability measurement in this research is done by using the Cronbach Alpha coefficient. There is a provision value in measuring the reliability by Cronbach Alpha statistical test. A construct is said to be reliable if the Cronbach Alpha > 0,700 (Ghozali in Nunnaly in Agustna and Yoestini, 2012). The reliability test result for variable $\mathrm{X}$ and $\mathrm{Y}$ in this research shows the Cronbach Alpha < 0, 7 so that the datum which are used in this research is reliable.

\section{Classic Assumption Test}

\section{Normality Test}

In this research, the normality test uses Kolmogorov-Smirnov test. The results obtained based on the significance (sig) value of the Kolmogorov-Smirnov test can be seen that the probability value for the equation model of this study is obtained by 0,322 and 0,291 . The probability value in normality test for each regression models is bigger than $5 \%$ or 0,05 shows that the estimated regression model follows the normal distribution.

\section{Heteroscedasticity test}

Based on the Scatterplot Output it can be seen that the data points are spread, not only at one point. The spreading of the data points has no pattern so that it can be conclude that there are any heteroscedasticity problems.

\section{Regression Equation Method}

In this research, there are two simple regression equations. The first equation is used to analyze the Sunset policy influence to the compliance of the individual retailer taxpayer in the area of KPP Pratama Majalaya in Bandung. The second equation is used to analyze the influence of the Tax Amnesty to the compliance of the individual retailer taxpayer in the area of KPP Pratama Majalaya in Bandung.

The equation model in this research is:

1) $\mathrm{Y} 1=1,705+0,621 . \mathrm{X} 1+\varepsilon$

$\alpha=1$, 705: means if the Sunset Policy is zero (0) so the compliance of the taxpayer is 1,705 .

$\beta=\mathrm{X} 1=0,621$ : means if the Sunset Policy increases as big as 1 level, so the compliance of the taxpayer increases as big as 0,621 .

$\varepsilon=$ error

2) $\mathrm{Y} 2=1,691+0,603 . \mathrm{X} 2+\varepsilon$ 
1, 691: means if the Amnesty Tax is zero (0) so the compliance of the taxpayer is 1,691

$\beta=\mathrm{X} 1=0,603$ : means if the $\operatorname{Tax}$ Amnesty increases as big as 1 level, so the compliance of the taxpayer increases as big as 0,603 .

$\varepsilon=$ error

\section{Coefficient of Determination}

Based on Ghozali (2013:97, coefficient of determination $\left(\mathrm{R}^{2}\right)$ basically to measure how far the model's ability to explain the variety of dependent variable.

In this research there are 2 coefficients of determinations to show whether there are inequality in influence between the variable Sunset Policy and the Tax Amnesty to the compliance of the taxpayer, in which the first coefficient of determination has resulted that the Adjusted R Square $=0,636$ or 63, 6\% it shows that the variable of difference of the compliance of the taxpayer can be explained by the Sunset Policy's variable as big as $63,6 \%$ while for the rest is as big as $36,4 \%$ is explained by the other causes out of the models. On the other hands, the second coefficient of determination has result that the Adjusted R Square $=0,547$ or $54,7 \%$ it shows that the variable of difference of the compliance of the taxpayer can be explained by Tax Amnesty variable as big as $54,7 \%$ while for the rest is as big as $45,3 \%$ is explained by the other causes out of the models. Therefore, it can be explained that there are difference in influence of the application of the Sunset Policy and Tax Amnesty to the compliances of the compliance of individual retailer's taxpayer in the area of KPP Pratama Majalaya in Bandung. In where the variable of the Sunset Policy gives bigger influence as big as 8 , 9\% compare with the Tax Amnesty to the compliances of the taxpayer's variable.

\section{Hypothesis Testing}

The result of the test states that $\mathrm{H} 1$ is accepted, which means there is the influence in the application of the Sunset Policy to the compliances of the individual retailer taxpayer in the area of KPP Pratama Majalaya in Bandung.

The result of the test states that $\mathrm{H} 2$ is accepted, which means there is the influence in the application of the Sunset Policy to the compliances of the individual retailer taxpayer in the area of KPP Pratama Majalaya in Bandung.

The result of the test states that $\mathrm{H} 3$ is accepted, which means there is the difference for the influence in the application of the Sunset Policy and the Tax Amnesty to the compliances of the individual retailer taxpayer in the area of KPP Pratama Majalaya in Bandung.

\subsection{Discussion}

The influence of Sunset Policy to the compliance of the individual retailer taxpayer in the area of KPP Pratama Majalaya in Bandung

The Sunset Policy gives the significant influence to the compliance of the individual retailer taxpayer in the area of KPP Pratama Majalaya in Bandung. It means the government puts the effort in this case the Sunset Policy which is able to increase the compliance of the individual retailer taxpayer in the area of KPP Pratama Majalaya in Bandung. The Sunset Policy causes the taxpayer to revise the SPT and make the NPWP without worrying about the additional for the administrative fine.

The influence of Tax Amnest to the compliance of the individual retailer taxpayer in the area of KPP Pratama Majalaya in Bandung

The Tax Amnesty gives the significant influence to the compliance of the individual retailer taxpayer in the area of KPP Pratama Majalaya in Bandung. It means the government puts the effort in this case the Tax Amnesty which is able to increase the compliance of the individual retailer taxpayer in the 
area of KPP Pratama Majalaya in Bandung. The Tax Amnesty is able to increase the income to the government from the taxpayer which previously never reports the assets that have not been taxed.

There is difference influence between the Sunset Policy and the Tax Amnest to the compliance of the individual retailer taxpayer in the area of KPP Pratama Majalaya in Bandung

There is difference influence between the Sunset Policy and the Tax Amnesty to the compliance of the individual retailer taxpayer in the area of KPP Pratama Majalaya in Bandung, in which the influence of the Sunset Policy is bigger than the Tax Amnesty to the compliance of the individual retailer taxpayer in the area of KPP Pratama in Bandung. Even though the difference is not significant, it is only about $8,9 \%$. However, it shows that the Sunset Policy is more successful than the Tax Amnesty. It happens because the Sunset Policy is more profitable for the taxpayer by setting free the administrative fine for the taxpayer who revises the SPT than

\section{REFERENCES}

Abdul Rahman. (2010) Panduan Pelaksanaan Administrasi Pajak: untuk karyawan, Pelaku Bisnis dan Perusahaan. Bandung: Nuansa.

Darussalam, Donny. (2014). Tax Amnesty dalam

Rangka Rekonsiliasi Nasional. Inside Tax, edisi 26, Desember.

Ghozali,I. (2013). Aplikasi Analisis Multivariate

dengan Program SPSS IBM SPSS 21 Update PLS Regresi. Edisi Ketujuh. Semarang: Badan Penerbit :Universitas Diponegoro.

Gunarto, Hari. (2016). Yang perlu Anda Tahu tentang Amnesti Pajak. the Tax Amnesty which still give influence the SPT report for the taxpayer in couple of years ahead.

\section{CONCLUSIONS}

\section{Conclusion}

Based on the description of the results of the research and discussion, conclusions can be taken as follows:

1. There is a significant effect of the variable sunset policy on the compliance of individual taxpayers of MSME retailers in the area of KPP Pratama Majalaya, Bandung.

2. There is a significant effect of the tax amnesty variable on individual taxpayer compliance in MSME retailers in the area of KPP Pratama Majalaya, Bandung

3. Sunset policy provides a greater influence than the tax amnesty on the compliance of individual taxpayers of MSME retailers in the area of KPP Pratama Majalaya, Bandung City.

\section{Retrieved}

fromhttp://www.beritasatu.com/eko nomi/383587-yang-perlu-andatahu-tentang-amnesti-pajak.htm

Hartono.(2011) Metodologi Penelitian. Zanafa Publishing.Pekanbaru

Malherbe,J. (2011 ). Tax Amnesties. Kluwer Law International BV,The Nerherlands.

Manurung, S. (2013). Kompleksitas Kepatuhan

Pajak. Retrieved September 18, 2015, fromhttp://www.pajak.go.id/content /article/kompleksitas-kepatuhanpajak

Mardiasmo. (2013). Perpajakan Edisi Revisi. Andi: Yogyakarta 
Nar,M. (2015). The Effects of Behavioral Economics on Tax Amnesty. International Journal of Economics and Financial Issues 5(2):580-589.

Priyanto, Dwi(2008). Mandiri Belajar SPSS. Mediakom. Yogyakarta

Pemerintah Republik Indonesia.(2007) Undangundang 28 tahun 2007. Perubahan Ketiga Atas Undang- undang no:6 tahun 1983 tentang Ketentuan Umum dan Tata Cara Perpajakan tanggal 17 Juli 2007. Jakarta.

Peraturan Menteri Keuangan Nomor 192/PMK.03/2007 Tentang Tata Cara Penetpan Wajib Pajak dengan Kriteria tertentu dalam Rangka Pengembalian Pendahuluan Keelebihan Pembayaran Pajak.

Sugiyono. (2011). Metode Penelitan Pendidikan. Alfabeta. Bandung

Suliyanto. (2006) Metode Riset Bisnis. Penerbit Andi. Yogyakarta.

Sunjoyo, et al.(2013). Aplikasi SPP Untuk Smart Riset. Alfabeta. Bandung.
Tambunan,Ruston. (2015, April 22).Mengupas Sunset Policy \& Tax Amnesty, Senjata Kejar Target Pajak. Retrieved from http://bisnis.liputan6.com/read/221 7599/mengupas-sunset-policy-amptax-amnesty-senjata-kejar-targetpajak

Undang-undang RI 2016 Tentang Pengampunan

Pajak.

Waluyo. (2011) Perpajakan Indonesia. Edisi 10. Salemba Empat: Jakarta

Wikipedia (2019, Maret 26).Sunset Policy. Retrieved from https://id.wikipedia.org/wiki/Sunset _policy

Wikipedia Indonesia.. (2016.Sept 3) Pengampunan Pajak. Retrieved from http://id.wikipedia.org/wiki/pengampunan_ pajak.Diakses 